DOI

\title{
ДИНАМІКА МІНЕРАЛЬНОÏ ЩІЛЬНОСТІ КІСТКОВОЇ ТКАНИНИ ТА ІНДЕКСУ МІНЕРАЛІЗАЦІї В ПІЗНІЙ ПЕРІОД ТРАВМАТИЧНОЇ ХВОРОБИ НА ТЛІ ЕКСПЕРИМЕНТАЛЬНОГО ПОСТМЕНОПАУЗАЛЬНОГО ОСТЕОПОРОЗУ
}

\author{
๑А. С. Машевський
}

\section{ДВНЗ «Тернопільський державний медичний університет імені І. Я. Горбачевського МОз України»}

\begin{abstract}
РЕЗЮМЕ. Моделювання скелетної і краніоскелетної травми супроводжується істотним порушенням мінеральної щільності кісткової тканини та індексу мінералізації кісткової тканини, яке суттєво вище через 1 міс. посттравматичного періоду у тварин із поєднаною краніоскелетною травмою. Моделювання травм через 30 ді6 після видалення гонад зумовлює суттєве зниження досліджуваних показників через 1 міс. посттравматичного періоду, які залишаються на такому ж рівні до 2 міс. експерименту. В цих експериментальних умовах порушення мінеральної щільності кісткової тканини та індексу мінералізації $\epsilon$ вірогідно меншими, ніж у тварин без гіпоестрогенного остеопорозу, що особливо виражено через 2 міс. експерименту.
\end{abstract}

КЛЮчОВІ СлОВА: менопауза, остеопороз, травма.

Вступ. Менопауза - це закономірний, пов'язаний з віком процес, ключовим механізмом якого є зниження функції яєчників і розвиток внаслідок цього дефіциту естрогенових гормонів. Дефіцит естрогенів в організмі жінок сприяє розвитку широкого спектра патологічних станів або прогресуванню наявних захворювань, відмічається неухильний ріст частоти опосередкованої менопаузою захворюваності. У зв'язку зі збільшенням середньої тривалості життя в більшості розвинених країн значно збільшується частка жінок в менопаузі, тому актуальність медико-соціальної реабілітації таких пацієнток з кожним роком зростає $[4,9]$.

Одним з основних органів-мішеней в умовах дефіциту естрогенів $\epsilon$ кісткова система, в якій внаслідок дисметаболічних порушень знижується маса кісткової тканини в одиниці об'єму і розвивається остеопороз. Внаслідок цього різко зростає крихкість кісток і схильність до переломів [10].

Характерною рисою сучасного урбанізованого суспільства $\epsilon$ зростання травматизму. За прогнозами аналітиків, до 2020 року травматизм стане основною причиною смерті у розвинених країнах у всіх вікових групах [11]. Тому проблема гіпоестрогенного остеопорозу набуває особливої актуальності, оскільки вірогідність тяжкої множинної і поєднаної травми кісток скелета в жінок у постменопаузальному періоді різко зросте. Однак у доступній літературі приділяється недостатня увага ролі гіпоестрогенного остеопорозу в патогенезі політравми і ремоделюванні кісткової тканини, що спонукає до поглибленого вивчення патогненетичних механізмів цих патологічних процесів та пошуку патогенетично обґрунтованих засобів корекції.

Мета дослідження - з'ясувати динаміку мінеральної щільності кісткової тканини та індексу мінералізації в пізній період травматичної хворо- би на тлі експериментального постменопаузального остеопорозу.

Матеріал і методи дослідження. Експерименти виконано на нелінійних білих щурах-самках масою 200-220 г. Модель постменопаузального остеопорозу виконували на нелінійних білих щурах-самках масою 200-220 г шляхом операційного видалення гонад [5]. Через 1 міс. в одній групі тварин моделювали ізольований перелом стегна, у другій - додатково викликали закриту черепно-мозкову травму (ЧМТ) ІІ ступеня тяжкості [3]. У групі порівняння зазначені травми моделювали у здорових тварин. Контрольну групу склали інтактні тварини та тварини із остеопорозом через 1 міс. після видалення гонад, яких не травмували. Усі оперативні втручання та нанесення травм здійснювали в умовах тіопентало-натрієвого наркозу

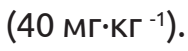

Контрольних тварин та травмованих тварин через 1 і 2 міс. посттравматичного періоду в умовах тіопентало-натрієвого знеболювання умертвляли методом тотального кровопускання з серця. Неушкоджену стегнову кістку очищали від м'яких тканин, зважували і визначали об'єм за кількістю витісненої води, як описано у праці [1]. За отриманими результатами розраховували мінеральну щільність кісткової тканини (МЩКТ). Активність лужної і кислої фосфатаз (відповідно ЛФ, КФ) визначали турбодиметричним методом на напівавтоматичному біохімічному аналізаторі «Humalazer 2000» з використанням наборів реактивів фірми «нuman» (Німеччина).

За активністю ЛФ і КФ розраховували індекс мінералізації [2]:

$$
\text { Індекс мінералізації (ум. од.) = ЛФ / КФ. }
$$

Усі експерименти виконано із дотриманням загальних правил і положень Європейської Кон- 
Огляди літератури, оригінальні дослідження, погляд на проблему

венції із захисту хребетних тварин, які використовуються для дослідницьких та інших наукових цілей (Страсбург, 1986), Загальних етичних принципів експериментів на тваринах (Київ, 2001), Закону України «Про захист тварин від жорстокої поведінки» (2006), а також відповідно до «Науково-практичних рекомендацій з утримання лабораторних тварин та роботи з ними» [8].

Отримані цифрові дані обробляли статистично. Вірогідність відмінностей між дослідними і контрольними групами оцінювали на основі непа- раметричного критерію Манна-Уітні з використанням програми STATISTICA ("StatSoft, Inc.», СШA).

Результати й обговорення. Як видно з таблиці 1, у ході моделювання скелетної травми у тварин без остеопорозу через 1 міс. МЩКТ ставала статистично вірогідно меншою, ніж у контролі, на $13,6 \%(p<0,05)$. Проте через 2 міс. посттравматичного періоду показник зростав і повертався до рівня контрольних тварин $(p>0,05)$. Його величина суттєво перевищувала аналогічний через 1 міс. спостереження (на 10,6\%, p<0,05).

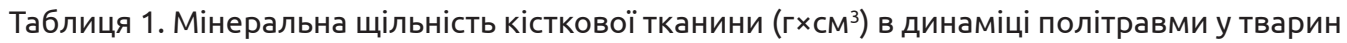
із гіпоестрогенним остеопорозом $(\mathrm{M} \pm \mathrm{m})$

\begin{tabular}{|c|c|c|c|c|c|}
\hline \multirow{2}{*}{$\begin{array}{c}\text { Умови } \\
\text { експерименту }\end{array}$} & \multirow{2}{*}{ Вид травми } & \multirow{2}{*}{ Вихідний стан } & \multicolumn{2}{|c|}{ Термін спостереження } & \multirow{2}{*}{$\mathrm{P}$} \\
\hline & & & 1 мiс. & 2 мiс. & \\
\hline \multirow{2}{*}{ Без остеопорозу } & скелетна травма & \multirow[t]{2}{*}{$\begin{array}{c}1,604 \pm 0,035 \\
(n=6)\end{array}$} & $\begin{array}{c}1,386 \pm 0,026^{*} \\
(n=6)\end{array}$ & $\begin{array}{c}1,533 \pm 0,044 \\
(n=6)\end{array}$ & $<0,05$ \\
\hline & $\begin{array}{l}\text { скелетна травма } \\
+ \text { ЧМТ }\end{array}$ & & $\begin{array}{c}1,446 \pm 0,027^{*} \\
(n=6)\end{array}$ & $\begin{array}{c}1,510 \pm 0,033 \\
(n=7)\end{array}$ & $>0,05$ \\
\hline \multirow{2}{*}{ Остеопороз } & скелетна травма & \multirow[t]{2}{*}{$\begin{array}{c}1,427 \pm 0,019^{\#} \\
(n=6)\end{array}$} & $\begin{array}{c}1,319 \pm 0,020 * \\
(n=7)\end{array}$ & $\begin{array}{c}1,287 \pm 0,018^{*} \\
(n=8)\end{array}$ & $>0,05$ \\
\hline & $\begin{array}{l}\text { скелетна травма } \\
+ \text { ЧМТ }\end{array}$ & & $\begin{array}{c}1,345 \pm 0,019 * \\
(n=7)\end{array}$ & $\begin{array}{c}1,302 \pm 0,018^{*} \\
(n=7)\end{array}$ & $>0,05$ \\
\hline \multicolumn{3}{|c|}{$\mathrm{P}_{1}$} & $>0,05$ & $<0,05$ & \\
\hline \multicolumn{3}{|c|}{$\mathrm{P}_{2}$} & $<0,05$ & $<0,05$ & \\
\hline
\end{tabular}

Примітки: тут і в табл. 2:

1. \# - відмінності між групами тварин з остеопорозом і без остеопорозу у вихідному стані статистично вірогідні (р<0,05);

2. ^ - відмінності між групами тварин із скелетною травмою та скелетною травмою в поєднанні із чмТ статистично вірогідні $(\mathrm{p}<0,05)$;

3. * - відмінності стосовно контрольної групи статистично вірогідні $(p<0,05)$;

4. p1 - вірогідність відмінностей тварин із скелетною травмою на тлі остеопорозу і без остеопорозу статистично вірогідні $(p<0,05)$;

5. p2 - вірогідність відмінностей тварин із скелетною травмою та ЧМТ на тлі остеопорозу і без остеопорозу статистично вірогідні $(p<0,05)$.

На тлі поєднання скелетної травми і чМТ через 1 міс. після нанесення травми МЩКТ теж знижувалася, порівняно з інтактними тваринами (на 9,8\%), що виявилося статистично вірогідним $(p<0,05)$. Через 2 міс. спостереження показник повертався до рівня інтактних тварин $(p>0,05)$, однак відмінності, порівняно з попереднім терміном спостереження, виявилися неістотними ( $>>0,05)$. Слід зазначити, що в умовах моделювання поєднаної краніоскелетної травми МЩКТ через 1 i 2 міс. посттравматичного періоду статистично вірогідно не відрізнялася, порівняно із тваринами, яким наносили тільки скелетну травму $(p>0,05)$.

В умовах видалення гонад через 1 міс. у піддослідних тварин МЩКТ, порівняно з інтактними тваринами, знижувалася на 11,3 \%, що виявилося статистично вірогідним $(p<0,05)$. Нанесення в цих умовах скелетної і поєднаної краніоскелетної травми супроводжувалося подальшим зниженням МЩКТ. Через 1 міс. порівняно із вихідним станом, показник ставав меншим відповідно на 7,6 i
$5,7 \%$ ( $p<0,05)$, через 2 міс. відповідно на 9,8 і 8,8 \% $(p<0,05)$. Відмінності між 1 і 2 міс. спостереження виявилися статистично не вірогідними $(p>0,05)$. Так само не виявлено суттєвих відмінностей за термінами спостереження й між групами із самою скелетною травмою та поєднаною краніоскелетною травмою $(p>0,05)$.

Порівнюючи дослідні групи тварин 3 гіпоестрогенним остеопорозом і без нього в динаміці посттравматичного періоду ми з'ясували, що після нанесення скелетної травми через 1 міс. спостереження відмінності між групами порівняння були статистично невірогідними ( $>>0,05)$, проте через 2 міс. МЩКТ була суттєво меншою у групі 3 видаленими гонадами (на $16,0 \%, \mathrm{p}_{1}<0,05$ ). Після моделювання поєднаної краніоскелетної травми МЩКТ вже через 1 міс спостереження на тлі гіпоестрогенного остеопорозу була істотно меншою (на $7,0 \%, \mathrm{p}_{2}<0,05$ ). Так само показник виявився статистично вірогідно меншим й через 2 міс. спостереження (на 13,8 \%, $\mathrm{p}_{2}<0,05$ ). 
Огляди літератури, оригінальні дослідження, погляд на проблему

Таким чином, моделювання скелетної і краніоскелетної травми у тварин без гіпоестрогенного остеопорозу, порівняно з інтактними тваринами, супроводжується істотним зниженням МЩКТ через 1 міс. посттравматичного періоду з наступним відновленням показника до 2 міс. експерименту. На тлі гіпоестрогенного остеопорозу МЩКТ через 1 міс. після нанесення обох травм суттєво знижується й залишається на такому ж рівні до 2 міс. експерименту. Видалення гонад супроводжується більшим порушенням МЩКТ, незалежно від виду травми, що особливо виражено через 2 міс. експерименту і відповідає максимуму зниження естрогенів в організмі піддослідних тварин [5].

Важливе значення у трактуванні впливу видалення гонад та травми на стан кісткової тканини має індекс мінералізації (табл. 2). Дослідження показали, що у тварин без остеопорозу, порівняно з інтактними тваринами, цей показник суттєво знижувався тільки через 1 міс. посттравматичного періоду: після скелетної травми - на 35,2 \% $(p<0,05)$, після краніоскелетної - на 52,7 \% ( $<<0,05)$. Слід відмітити, що поєднана травма зумовлювала більше порушення досліджуваного показника, ніж моноскелетна травма (на 27,0 \%, p<0,05). Через 2 міс. наставала нормалізація індексу мінералізації як після нанесення самої скелетної, так і поєднаної краніоскелетної травми $(p<0,05)$. В обох дослідних групах показник суттєво зростав, порівняно з попереднім терміном спостереження: на тлі скелетної травми - на $41,4 \%(p<0,05)$, на тлі краніоскелетної - на 84,0 \% ( $p<0,05)$.

Таблиця 2. Величина індексу мінералізації кісткової тканини (ум. од.) в динаміці політравми у тварин із гіпоестрогенним остеопорозом (M $\pm \mathrm{m})$

\begin{tabular}{|c|c|c|c|c|c|}
\hline \multirow{2}{*}{$\begin{array}{c}\text { Умови } \\
\text { експерименту }\end{array}$} & \multirow{2}{*}{ Вид травми } & \multirow{2}{*}{ Вихідний стан } & \multicolumn{2}{|c|}{ Термін спостереження } & \multirow{2}{*}{$\mathrm{P}$} \\
\hline & & & 1 мic. & 2 мic. & \\
\hline \multirow{2}{*}{ Без остеопорозу } & скелетна травма & \multirow[t]{2}{*}{$\begin{array}{c}39,56 \pm 1,86 \\
(n=6)\end{array}$} & $\begin{array}{c}25,63 \pm 1,26 * \\
(n=6)\end{array}$ & $\begin{array}{c}36,25 \pm 1,88 \\
(n=6)\end{array}$ & $<0,05$ \\
\hline & скелетна травма + ЧМТ & & $\begin{array}{c}18,70 \pm 0,62^{* \wedge} \\
(n=6)\end{array}$ & $\begin{array}{c}34,40 \pm 2,48 \\
(n=7)\end{array}$ & $<0,05$ \\
\hline \multirow{2}{*}{ Остеопороз } & скелетна травма & \multirow[t]{2}{*}{$\begin{array}{c}27,20 \pm 1,52^{\#} \\
(n=6)\end{array}$} & $\begin{array}{c}18,40 \pm 0,67^{*} \\
(n=7)\end{array}$ & $\begin{array}{c}19,74 \pm 1,37 * \\
(n=8)\end{array}$ & $>0,05$ \\
\hline & скелетна травма + ЧМТ & & $\begin{array}{c}14,22 \pm 0,83 * \wedge \\
(n=7)\end{array}$ & $\begin{array}{c}12,91 \pm 0,74 * \\
(n=7)\end{array}$ & $>0,05$ \\
\hline \multicolumn{3}{|c|}{$\mathrm{P}_{1}$} & $<0,05$ & $<0,05$ & \\
\hline \multicolumn{3}{|c|}{$\mathrm{P}_{2}$} & $<0,05$ & $<0,05$ & \\
\hline
\end{tabular}

В умовах моделювання гіпоестрогенного остеопорозу через 1 міс. після видалення гонад індекс мінералізації ставав на 31,2 \% меншим, ніж в інтактних тварин ( $<<0,05)$. Після нанесення на цьому тлі скелетної травми показник через 1 міс. знижувався на 32,3 \% ( $<<0,05)$, порівняно з вихідним станом) і залишався на практично такому ж рівні до 2 міс. спостереження ( $p>0,05)$. В умовах поєднаної краніоскелетної травми через 1 міс. посттравматичного періоду зниження індексу мінералізації було більш відчутним - на 47,7 \% ( $<<0,05)$, що також виявилося істотно меншим, ніж після самої скелетної травми (на 22,7 \%, р<0,05). Через 2 міс. показник ще більше знижувався і ставав на 52,5 \% меншим, ніж у вихідному стані ( $<<0,05)$, проте статистично вірогідно не відрізнявся від величини попереднього терміну спостереження ( $>00,05)$.

Порівнюючи дослідні групи з остеопорозм і без остеопорозу ми з'ясували, що у всі терміни спостереження на тлі остеопорозу індекс мінералізації був суттєво меншим: на тлі скелетної травми через 1 міс. - на 28,2 \% (р<0,05), через 2 міс. - на 45,5 \% ( $\left.p_{1}<0,05\right)$; після краніоскелетної травми - відповідно на 24,0 і 62,5\% ( $\left.p_{2}<0,05\right)$.
Таким чином, індекс мінералізації через 1 і 2 міс. після нанесення скелетної травми суттєво менший, ніж в інтактних тварин. Порушення $\epsilon$ більш вираженими після нанесення краніоскелетної травми, особливо через 1 міс. посттравматичного періоду. Моделювання травм через 1 міс. після видалення гонад зумовлює у всі терміни суттєво більші порушення, ніж у тварин з аналогічними травмами без видалення гонад.

Отримані результати вказують на те, що модельована краніоскелетна травма викликає зниження МНЩК та індексу мінералізації, що зумовлено активацією остеобластів та посиленням процесів резорбції кісткової тканини, зумовлене факторами травматичної хвороби [6]. Отримані порушення, очевидно, викликані впливом прозапальних цитокінів, які утворюються внаслідок травми [7]. Такі цитокіни як інтерлейкін-1, туморнекротичний фактор-альфа, інтерлейкін-6 сприяють підвищеному утворенню остеобластів, що призводить до посиленої резорбції кістки [12]. Із збільшенням тяжкості травми порушення МЩКТ та індексу мінералізації ставали більшими, 
Огляди літератури, оригінальні дослідження, погляд на проблему

що, очевидно, зумовлено більшим утворенням медіаторів запалення. В умовах видалення гонад порушення МЩКТ та індексу мінералізації були більшими. Ймовірно, має місце нашарування патогенних механізмів, пов'язаних із дефіцитом естрогенів та системним впливом факторів травматичної хвороби.

Отримані результати націлюють на пошук ефективних засобів, націлених на ремоделювання кісткової тканини в умовах тяжкої травми та дефіциту естрогенів.

Висновки. 1. Моделювання скелетної і краніоскелетної травм супроводжується істотним порушенням МЩКТ та індексу мінералізації кісткової тканини, яке суттєво вище через 1 міс. пост- травматичного періоду у тварин із поєднаною краніоскелетною травмою.

2. Моделювання травм через 30 діб після видалення гонад зумовлює суттєве зниження досліджуваних показників через 1 міс. посттравматичного періоду, які залишаються на такому ж рівні до 2 міс. експерименту. В цих експериментальних умовах порушення МЩКТ та індексу мінералізації $\epsilon$ вірогідно меншими, ніж у тварин без гіпоестрогенного остеопорозу, що особливо виражено через 2 міс. експерименту.

Перспективи подальших досліджень. у перспективі будуть апробовані різні технології корекції ремоделювання кісткової тканини в умовах травми та гіпоестрогеного остеопорозу.

\section{ЛІТЕРАТУРА}

1. Автандилов Г. Г. Основы количественной патологической анатомии / Г. Г. Автандилов. - М. : Медицина, 2002. -240 с.

2. Березовская О. П. Остеогенез в условиях гипокинезии и гипоксии / О. П. Березовская, И. Г. Литовка // Проблеми екологічної та медичної генетики і клінічної імунології. Збірник наукових праць. - Київ; Луганськ; Харків, 2002. - Вип. 6 (45). - С. 19-31.

3. Ельский В. Н. Моделирование черепно-мозговой травмы / В. Н. Ельский, С. В. Зяблицев. - Донецк : Изд-во “Новый мир”, 2008. - 140 с.

4. Захурдаева Л. Д. Эстрогены: биологические и фармакологические эффекты / Л. Д. Захурдаева // Мед. аспекты здоровья женщины. - 2010. - № 8. - С. 41-45.

5. Камышников В. С. Клинико-лабораторный мониторинг биохимических маркеров остеопороза в эксперименте / В. С. Камышников, Ю. Д. Коваленко, Н Н. Кохнович // Достижения медицинской науки Беларуси .2003. - http://med.by/dmn/book.php?book=03-18_10.

6. Левицький А. П. Використання препарату Остеовіту для профілактики глюкокортикоїдного остеопорозу / А. П. Левицький, О. А. Макаренко // Ендокринологія. - 2008. - Т. 13, № 1. - С. 92-97.

7. Малыш И. Р. Профиль цитокинов в динамике посттравматического периода у пострадавших с тяже- лой политравмой / Малыш И. Р., Козлов В. К., Згржебловская Л. В. // Український журнал екстремальної медицини імені Г. О. Можаєва. - 2005. - Т. 6, № 3. C. $66-78$.

8. Науково-практичні рекомендації з утримання лабораторних тварин та роботи з ними / Ю. М. Кожем'якін, О. С. Хромов, М. А. Філоненко, Г. А. Сайфетдінова - Київ : Авіцена, 2002. -156 с

9. Поворознюк В. В. Иммунологические аспекты постменопаузального остеопороза / В.В.Поворознюк, Н. А. Резниченко, Э. А. Майлян // Боль. Суставы. Позвоночник. - 2013. - № 3. - С. 21-26.

10. Поворознюк В. В. Регуляция эстрогенами ремоделирования костной ткани / В. В. Поворознюк, Н. А. Резниченко, Э. А. Майлян // Репродуктивная эндокринология. - 2014. - № 1. - С. 14-18.

11. Рощін Г. Г. Багатофакторний аналіз летальності при поєднаній травмі органів черевної порожнини / Г. Г. Рощін, В.І.Іванов, В. О. Крилюк // Клінічна хірургія. - 2013. - № 4. - С. 40-44.

12. Чернов Ю. Н. Остеопороз: критические звенья патогенеза и пути фармакологической коррекции / Ю. Н. Чернов, Л. К. Пешехонова // В мире лекарств. 2000. - № 2. - С. 44-50. 


\section{Horbachevsky Ternopil State Medical University}

SUMMARY. Modeling of skeletal and cranio-skeletal injuries is accompanied by a significant breach of bone mineral density and bone mineralization index, which is significantly higher in 1 month of post-traumatic period in the animals with a combined cranio-skeletal injury. Modeling injuries in 30 days after the removal of the gonads leads to a significant reduction in the studied parameters after 1 month of post-traumatic period, remaining at the same level for 2 months of the experiment. In these experimental conditions, violations of bone mineral density and salinity index is significantly lower than in animals without hyoestrogenic osteoporosis, which is especially pronounced after 2 months of the experiment.

KEY WORDS: menopause, osteoporosis, injury. 